\title{
A Perspective on Prostate Carcinogenesis and Chemoprevention
}

\author{
Maarten C. Bosland ${ }^{1} \cdot$ Nur Özten ${ }^{2} \cdot$ Jillian N. Eskra $^{1}$ • \\ Abeer M. Mahmoud ${ }^{1}$
}

Published online: 11 April 2015

(C) Springer International Publishing AG 2015

\begin{abstract}
In this perspective, modifiable carcinogenic factors for the prostate are summarized. This is followed by a discussion of how current knowledge about causation of prostate cancer and chemoprevention of prostate cancer can be used to develop preventive strategies. Prostate cancer is a slowly developing cancer which offers opportunities for preventive interventions. Only a few randomized clinical trials of prostate cancer prevention have been completed. The SELECT study with selenium and vitamin $\mathrm{E}$ did not find protective effects, but in two trials with $5 \alpha$-reductase inhibitors risk was reduced about $25 \%$, showing that chemoprevention is possible and indicating that the androgen receptor is a suitable target. Besides smoking cessation and reduction of obesity, there are no known dietary or life style interventions that will have a major impact on prostate cancer risk. Inflammation of the prostate is an attractive target, and aspirin may be a promising candidate agent, but has not been addressed yet in preclinical and clinical studies. Antioxidants other than selenium and vitamin $\mathrm{E}$ are unlikely to be very effective and data on several dietary supplements are not encouraging. More candidate agents need to be identified and tested in relevant and adequate preclinical models and phase II trials that have predictive value for outcome of phase III randomized studies. Doing this will require a systematic approach comparing preclinical
\end{abstract}

This article is part of the Topical Collection on Cancer Chemoprevention

Maarten C. Bosland

boslandm@uic.edu

1 Department of Pathology, University of Illinois at Chicago, 840 South Wood Street, Room 130 CSN, Chicago, IL 60612, USA

2 Faculty of Pharmacy, Bezmiâlem Vakif University, 34093 Fatih, Istanbul, Turkey and clinical study outcomes to determine their predictive value of preventive efficacy.

Keywords Prostate cancer - Carcinogenesis . Chemoprevention $\cdot$ Antioxidants $\cdot$ Hormones

\section{Introduction}

The idea that cancer can be prevented implies that its causation is known, so that the causes can be eliminated (primary prevention such as smoking cessation); or that the mechanism by which causative factors act are understood so that they can be interfered with by chemopreventive or dietary interventions preventing development of cancer or preneoplastic lesions that may progress to cancer. For slowly growing and slowly progressing cancers, inhibition of growth and a delay of progression to more aggressive malignancy may also be effective. Prostate cancer is an example of such a slow developing cancer for which there is often a long period between development of the first malignant glands and the emergence of aggressive and fast growing tumors that are fatal. This explains why small cancers are found at autopsy in as many as $30 \%$ of men between the ages of 30 and 60 years and as much as 45 $75 \%$ of men between 60 and 80 years [1,2]. Thus, to prevent for prostate cancer, we must understand both causation and mechanism of growth and progression in order to create preventive strategies to interfere with the development of this malignancy, particularly fatal cancer.

A separate question is whether risk of prostate cancer is modifiable and prevention of progression is possible. The answer to this question is probably yes, but conclusive evidence is lacking. Studies of migrants from low risk to high risk countries, such as men moving from Japan to the USA, have shown that risk is highly modifiable in the high risk direction, 
implicating life style factors, probably diet, as major risk determinants [3]. However, there are no studies of men moving from high to low risk areas in the world. There have been only a few true prevention randomized clinical trials (RCTs) of prostate cancer, one with selenium and vitamin $\mathrm{E}$ in which no protective effects were found [4], and two studies with drugs that inhibit $5 \alpha$-reductase which reduced risk by about $25 \%$ [5], showing that prevention is possible.

Another issue is whether prostate cancer needs to be prevented and what type of prostate cancer should be prevented. Prostate cancer is diagnosed in about 230,000 annually, and approximately 30,000 men die from this malignancy every year in the USA; prostate cancer is thus the most prevalent malignancy and the second most common cause of cancer death in US men [6]. Clearly, this is a major human cancer. Although the majority of prostate cancers is not fatal, this malignancy still accounts for $10 \%$ of all male US cancer deaths ahead of colorectal and pancreatic cancer [6]. Prevention of prostate cancer, particularly the aggressive and fatal form of this malignancy, is thus an important objective.

In this perspective, modifiable carcinogenic factors for the prostate will be summarized followed by a discussion of chemoprevention of prostate cancer and how current knowledge about causation of prostate cancer can be used to identify preventive strategies. There is no attempt to be complete or address many mechanistic issues; instead, the focus is on efficacy and relevance, on successes and failures, and on ways to move forward with chemoprevention.

\section{Prostate Carcinogenesis}

What is known about the causes of prostate cancer? The answer is not much. Even though the aforementioned migrant studies strongly suggest that dietary factors are very important risk determinants, major dietary risk factors have been elusive [7]. There are several important non-modifiable risk factors, such as age, race/ethnicity, familial history of prostate cancer, and still poorly defined genetic susceptibility, but these will not be discussed here because they do not offer preventive opportunities.

\section{Dietary Factors}

There is no strong evidence that high intake of meats or fat and low intake of fruits and vegetables increase risk [8-11] and that consumption of antioxidants, fish, or a Mediterranean diet would lower risk [12-14], while data on diary intake are mixed $[9,15,16]$. Thus, it is not clear which dietary factors have to be reduced in intake and which need to be consumed in increased amounts to prevent prostate cancer [17, 7]. Furthermore, it is not clear how these factors mechanistically act [18 $]$. Although many have proposed dietary guidelines to reduce prostate cancer rates [19], there is currently no real evidence to indicate that this approach has preventive results. The vast majority of data comes from epidemiological studies, and there are no published RCTs of diet modifications to reduce prostate cancer risk [20]. Obesity is a risk factor for fatal prostate cancer, and weight reduction may offer a way to modify prostate cancer mortality through dietary and energy expenditure approaches; however, this has not yet been tested in RCTs [21,22].

\section{Hormonal Factors}

Hormones, particularly androgens and estrogens, have been widely considered involved in prostate carcinogenesis, but evidence from human studies, mostly from epidemiological studies, is either lacking or null [23, 24]. Nonetheless, the biology of prostate cancer strongly suggests that androgens and possibly estrogens are involved as causative factors $[25 \cdot, 26,27]$. Indeed, treatment of rats with testosterone induces prostate carcinomas [28•]. If these steroid hormones act via their nuclear receptors, interventions that block their action may offer opportunities for prevention. But because these hormones have many essential functions, this approach may pose a risk of serious side effects. Other activities of steroid hormones may be involved as well. There is evidence that testosterone can have pro-oxidant properties [29,30], and oxidative stress may thus be mechanistically involved.

Estrogen is formed in the male from androgens by the aromatase enzyme encoded by the CYP19 gene [31] in various tissues, including the prostate [32]. Because there are estrogen receptors in the prostate (both ER- $\alpha$ and ER- $\beta$ ) [33], there is plausibility for a biological effect of estrogen in the prostate and possibly prostatic carcinogenesis. $17 \beta$-Estradiol and estrone can be converted by CYP1B1 and CYP1A1 to 4and 2-hydroxylated catecholestrogens, respectively, which can undergo redox cycling resulting in the formation of highly reactive estrogen-quinones and reactive oxygen species (ROS) $[34,35]$. ROS can directly and indirectly damage DNA and cause mutations, and the estrogen-quinones can cause depurinating DNA adducts that can lead to mutations as well $[35,36]$. Thus, it is plausible that testosterone can cause cancer of the prostate, acting via the androgen receptor and via conversion to estrogen activating estrogen receptors and inducing genotoxicity due to formation of reactive species.

\section{Prostatitis}

Prostatitis, inflammation of the prostate, has long been considered a risk factor for prostate cancer [37, 38]. Some recent studies support that notion [39॰], whereas others do not [40, 41]. Inflammation results in generation of ROS which may cause DNA damage, aggravate the inflammatory process by causing tissue damage and release of inflammatory mediators, 
and often causes increased cell proliferation as reaction of prostatic epithelium. Indeed, hyper-proliferation occurs in post-inflammatory atrophic acini in the prostate which lesion, proliferative inflammatory atrophy, has been associated with formation or preneoplastic and malignant lesions in the human prostate [39॰].

\section{Carcinogens}

Exposure to specific carcinogens has not been associated with risk of prostate cancer in humans, but several structurally diverse chemical carcinogens have caused prostate cancer in laboratory animals, mostly rats; this occurs if the carcinogens are metabolically activated in the prostate [42-45], if the prostate is made susceptible by inducing cell proliferation at the time of carcinogen exposure [46, 47], or if a strong tumor promoting stimulus by androgens is given post-carcinogen exposure [48]. Recent evidence indicates that cigarette smoking, particularly heavy smoking, increases the risk of prostate cancer $[49,50]$. Thus, overall exposure to carcinogenic chemicals may be a risk factor with susceptibility and tumor promotion by androgens as critical determinants.

\section{Chemoprevention}

In the previous section, hormonal factors and prostatitis have been identified as possible targets for chemoprevention as well as avoidance of carcinogen exposure, including smoking, and bodyweight reduction as potential ways to reduce risk. However, one should keep in mind that the populationattributable risk of smoking is probably not high $(<10 \%)$ [49] and that of obesity is not clear [21]. Nonetheless, avoidance of smoking and obesity will result in fewer deaths from prostate cancer, in addition to a much larger benefit in terms of reduction of lung cancer, cardiovascular disease, and metabolic syndrome.

\section{Hormonal Targets}

Antiandrogens that block the androgen receptor are very effective in preventing prostate cancer in rats treated with a prostate-targeted carcinogen and chronic testosterone administration [51], but are not acceptable for use in men because of side effects. Instead, intracellular levels of the active testosterone metabolite $5 \alpha$-dihydrotestosterone (DHT) can be reduced by treatment with inhibitors of $5 \alpha$-reductase which mediates DHT formation. In two RCTs with $5 \alpha$-reductase inhibitors (finasteride and dutasteride) [52, 53], a $25 \%$ reduction of men diagnosed with prostate cancer [5]. However, because these treatments only reduced low grade prostate cancer and slightly increased risk of high grade cancer, the FDA did not approve them for prevention of prostate cancer [54], and they are not widely used of label for this purpose.

Two estrogen receptor blocking agents were not active against prostate cancer; toremifene was not active in a RCT [55], and tamoxifen was inactive in rats treated with a prostate-targeted carcinogen and chronic testosterone administration [51]. No studies have attempted to specifically interfere with the genotoxic affects of estrogen, and this remains an unexplored potential chemoprevention target [25•]; ROS as targets are discussed below.

\section{Inflammation and ROS as Targets}

Clearly, inflammatory processes and the formation of ROS are attractive targets for chemoprevention. Dietary antioxidants targeting ROS, however, have not been active and in some cases even harmful. Selenium in the form of selenomethionine and vitamin $\mathrm{E}$ in the form of $\alpha$-tocopherol did not prevent prostate cancer in the large SELECT trial of men with low PSA $(<4.0 \mathrm{ng} / \mathrm{ml})[4]$. Both agents actually increased risk of prostate cancer slightly, selenium only in a subset of subjects $[56 \bullet, 57 \bullet]$. Selenomethionine did not affect risk of progression to prostate cancer in men with high grade prostatic intraepithelial neoplasia (PIN) [58], and selenized yeast did not affect risk in men with elevated PSA or other high risk indicators who were negative on biopsy [59]. Selenomethionine and selenized yeast were also negative in studies with rat models of prostate cancer [60, 61]. In one of these studies, $\alpha$-tocopherol increased the incidence of prostate cancer, similar to the results of SELECT [60]. We found that selenium at physiological concentrations increased cell proliferation in LNCaP prostate cancer cells in vitro, but inhibited proliferation at higher doses [62]. These findings can be interpreted as consistent with a postulated U-shaped dose response for selenium and cancer preventive effects [63]. We did not find a reduction of oxidative stress and preneoplastic lesions in the prostate of rats fed selenomethionine and minimal effects on antioxidant enzymes [64]; this is consistent with the null effects observed in abovementioned animal studies and clinical trials with selenium supplementation. The baseline selenium status of the subjects involved in RCTs may be of particular importance relevant to whether selenium prevents prostate cancer or is harmful [65]. Baseline vitamin E status may also affect selenium efficacy [57•]. The current evidence for another strong antioxidant, lycopene, to prevent prostate cancer is also weak [66, 67], although intake of tomato products appears to be protective [9].

The potential for some antioxidants to increase rather than reduce risk of prostate cancer, as was found for selenium and vitamin $\mathrm{E}$ in the SELECT trial and for vitamin $\mathrm{E}$ in a rat study, is disconcerting and may be a risk associated with antioxidants in general. In a recently published study of lung cancer in transgenic mice, $N$-acetylcysteine and vitamin $\mathrm{E}$ both 
increased tumor progression and cancer-related mortality [68]. The findings from this study suggest that disruption of the balance between ROS formation, DNA damage, and the p53-related DNA damage response may be responsible for this. It is conceivable that there are optimal antioxidant doses for preventive activity. Higher doses may cause tumor promotion or pro-oxidant activity; such doses may be tumor typeand antioxidant-specific and dependent on "base-line" antioxidant status and degree of pre-existing DNA damage or mutations. This notion would be in line with the abovementioned U-shaped dose response for selenium and prostate cancer preventive activity.

Anti-inflammatory drugs have not been tested for preventive activity against prostate cancer in humans, but there are some animal studies indicating that the COX-2 inhibitors celecoxib and sulindac have chemopreventive effects [69], but the NSAID non-selective COX inhibitor piroxicam was negative (McCormick \& Bosland, unpublished data). For aspirin, there are meta-analysis data of observational studies that suggest a preventive effect [70-72], but there are no results from RCTs or animal studies. Because of the lower safety concerns for aspirin compared to celecoxib, it is likely that human studies of the chemopreventive activity of aspirin will be undertaken [73].

\section{Dietary Supplements and Drugs}

Besides antioxidants, dietary supplements that are commonly taken include vitamin D and calcium. Vitamin D has been proposed to prevent prostate cancer, but recent epidemiologic data suggest that this may not be the case or that there is a Ushape dose response relationship between plasma vitamin D and risk of prostate cancer [74]. In any case, vitamin D toxicity limits its potential use as a chemoprevention agent [75]. Calcium supplements may be prostate cancer enhancing at high doses and should probably not exceed 1,000 mg per day [9]. The association between calcium and prostate cancer may be the reason for milk consumption to be associated with increased risk of this malignancy and modulation of vitamin D metabolism by calcium may be the underlying mechanism $[76,77]$. Silibinin derived from the milk thistle plant has a range of anti-cancer activities and is particularly active against prostate cancer [78]. This agent is being developed for testing in human clinical trials, and milk thistle extract has been tested for carcinogenic and toxic effects in animals and is largely safe [79].

Berries, especially black raspberries, have been shown to possess anticancer activity against gastrointestinal diseases including cancer in experimental animals and humans [80, 81]. These berries are very rich in antioxidant compounds, such as ellagic acid and various anthocyanins that also affect carcinogen metabolism and a number of signaling pathways [81]. In unpublished studies, we used two different rat models to test the prostate cancer chemopreventive activity of freeze dried black raspberries mixed into the diet up to $10 \%$ by weight, but found no preventive efficacy. This was surprising, because we could detect the anthocyanin metabolite protocatechuic acid in prostate tissue of rats fed diets containing black raspberries. We also did not find any in vitro growth inhibitory activity of protocatechuic acid and the anthocyanin cyanidin-3-rutinoside, while ellagic acid was growth inhibitory only at concentrations unattainable in vivo. However, ellagic acid reduced prostate cancer development in a SV40 $\mathrm{T}$ antigen transgenic prostate carcinogenesis rat model [82].

Soy consumption is associated with a modest reduction in risk of prostate cancer [83, 84•], and it has been proposed to have prostate cancer preventive properties because of its richness in isoflavones with anti-cancer activity, particularly genistein [85]. Genistein inhibits growth of human prostate cancer cells that have wild type androgen receptor. However, it stimulates growth at physiologically attainable concentrations in cell lines that carry certain androgen receptor mutations, such as LNCaP cells; these mutations can arise in tumors that have become castration resistant after failing to respond to hormone ablation therapy [86]. Although there are several studies that have examined the effect of soy supplements on PSA $[87,88]$, there are only two that have studied effects on cancer development. We did not find reduction or delay of biochemical recurrence after radical prostatectomy in a RCT of men at high risk for recurrence given a daily supplement of soy protein isolate [89]. Fleshner et al. [90] did not find an effect on progression from high-grade PIN to prostate cancer in a RCT of men consuming a mixture of soy protein and vitamin E plus selenium (forms of vitamin $\mathrm{E}$ and selenium were not specified). Thus, there is no current evidence from clinical trials that soy prevents prostate cancer.

Green tea and its extracts contain several compounds that have a range of anti-cancer activities [91]. A green tea catechin mixture reduced the number of men with high-grade PIN developing prostate cancer in a small RCT $[92,93]$. However, a RCT with presurgical administration of a similar mixture, polyphenon $\mathrm{E}$, indicated absence of effects on markers of proliferation, apoptosis, and angiogenesis in prostate tissue and low bioavailability of tea catechins to the prostate [94]. We did not find protective activity of green tea extract on chemical-hormonal induction of prostate cancer in rats (unpublished results). Although more clinical studies are ongoing [95], it seems unlikely at present that green tea provides a substantive amount of protection against prostate cancer development.

Pomegranate juice or extracts have been studied because of their richness in antioxidant compounds and anti-cancer effects [96]. Despite two encouraging small phase II studies $[97,98]$, a larger randomized study with pomegranate extract given to men before radical prostatectomy did not find any effects on relevant intermediate biomarkers, despite uptake in 
the prostate of a metabolite found in pomegranate [99]. On the other hand, pomegranate juice and ellagic acid found in that juice reduced prostate cancer development in a SV40 T antigen transgenic prostate carcinogenesis rat model [82].

Vitamin $\mathrm{E}$ is the generic term for a family of naturally occurring tocopherols. Although $\alpha$-tocopherol does not appear to provide protection against prostate cancer development (see above), other tocopherols, particularly $\gamma$ tocopherol and possibly $\delta$-tocopherol, may have protective activity $[100,101]$. Future studies are necessary to sort this out.

Resveratrol and curcumin have not been tested as yet in RCTs or even relevant animal models [102•]. The diabetes drug metformin and cholesterol-lowering statins have been proposed as potential candidate agents largely on the basis of epidemiological data, but RCT results and data from relevant preclinical models are lacking $[102 \cdot, 103 \bullet \bullet]$.

\section{Research Needs}

The field of prostate cancer chemoprevention has been in crisis ever since the failure of SELECT and the refusal by the FDA to approve $5 \alpha$-reducase inhibitors for use to prevent this malignancy. In part, this is the result of (1) the lack of effective approaches to identify agents with low toxicity but considerable promise to be efficacious, (2) uncertainty about which in vivo models are most predictive of outcomes in RCTs, (3) difficulties in conducting phase II trials, in terms of both accrual problems and lack of information about predictive value of intermediate biomarkers that should be the hallmark of such trials, and (4) absence of a systematic evaluation of outcomes of animal models, Phase II trials, and definitive phase III RCTs. All four of these aspects will require a substantive research effort to resolve, and unless such a systematic effort is undertaken, progress will remain spotty and probably largely unsuccessful.

Of note, human prostate cancer cell models used to test agents may help identify potentially promising compounds, but are not appropriate chemoprevention models because they represent advanced prostate cancer, and the TRAMP mouse model is no longer considered an appropriate model of adenocarcinoma of the prostate since it develops neuroendocrine tumors [104].

\section{Concluding Remarks}

The above summary of carcinogenesis and chemoprevention of prostate cancer indicates that we know too little about avoidable causes of prostate cancer that can be used to develop preventive strategies and that progress on chemoprevention, including dietary supplements, has to date been largely unsuccessful. Besides examining the effects on prostate cancer risk of smoking cessation and efforts to reduce the prevalence of obesity and increase healthy dietary habits, it will be important to continue a focus on dietary supplements that emerge as potential candidate prostate cancer chemoprevention agents. Dietary supplements are often not very toxic and typically have multiple mechanisms of action, particularly in the case of supplements that are extracts or other mixtures such as green tea and soy protein.

Although studies with antioxidants have been unsuccessful to prevent prostate cancer (see above), there are some agents that have some promise in this regard and need to be studies in more detail such as $\gamma$ - and $\delta$-tocopherols and the methyl selenium compounds methylseleninic acid and Semethylselenocysteine $[105,106]$. Aspirin in particular may offer some promise given its ability to interfere with colon cancer formation and its already wide use to prevent clotting [107]. However, more candidate agents need to be identified and tested in relevant and adequate animal models and phase II trials that have predictive value for outcome of phase III RCTs. Given the uncertainty of how to identify such agents and which animal models and phase II trial designs are most appropriate, much more systematic research is needed to move forward with chemoprevention of prostate cancer. Although recent failures has dampened enthusiasm for prostate cancer chemoprevention, developing effective strategies prevention needs to remain a high priority in view of the considerable prevalence and mortality of this malignancy in the USA, Europe, and elsewhere in world.

Acknowledgments This work was supported by grants CA103215, CA104334, and CA116195 (M.C. Bosland) from the U.S. National Cancer Institute and grants from the Prevent Cancer Foundation.

\section{Compliance with Ethics Guidelines}

Conflict of Interest Maarten C. Bosland, Nur Özten, Jillian N. Eskra, and Abeer M. Mahmoud declare that they have no conflict of interest.

Human and Animal Rights and Informed Consent This article does not contain any studies with human or animal subjects performed by any of the authors.

\section{References}

Papers of particular interest, published recently, have been highlighted as:

- Of importance

•- Of major importance

1. Powell IJ, Bock CH, Ruterbusch JJ, Sakr W. Evidence supports a faster growth rate and/or earlier transformation to clinically significant prostate cancer in black than in white American men, and influences racial progression and mortality disparity. J Urol. 2010;183:1792-6.

2. Zlotta AR, Egawa S, Pushkar D, Govorov A, Kimura T, Kido M, et al. Prevalence of prostate cancer on autopsy: cross-sectional 
study on unscreened Caucasian and Asian men. J Natl Cancer Inst. 2013;105:1050-8.

3. Wynder EL, Fujita Y, Harris RE, Hirayama T, Hiyama T. Comparative epidemiology of cancer between the United States and Japan. A second look. Cancer. 1991;67:746-63.

4. Lippman SM, Klein EA, Goodman PJ, Lucia MS, Thompson IM, Ford LG, et al. Effect of selenium and vitamin E on risk of prostate cancer and other cancers: the Selenium and Vitamin E Cancer Prevention Trial (SELECT). JAMA. 2009;301:39-51.

5. Wilt TJ, Macdonald R, Hagerty K, Schellhammer P, Tacklind J, Somerfield MR, et al. 5-alpha-Reductase inhibitors for prostate cancer chemoprevention: an updated Cochrane systematic review. BJU Int. 2010;106:1444-51.

6. Siegel R, Ma J, Zou Z, Jemal A. Cancer statistics, 2014. CA Cancer J Clin. 2014;64:9-29.

7. Wilson KM, Giovannucci EL, Mucci LA. Lifestyle and dietary factors in the prevention of lethal prostate cancer. Asian J Androl. 2012;14:365-74.

8. Alexander DD, Mink PJ, Cushing CA, Sceurman B. A review and meta-analysis of prospective studies of red and processed meat intake and prostate cancer. Nutr J. 2010;9:50.

9. Dagnelie PC, Schuurman AG, Goldbohm RA, Van den Brandt PA. Diet, anthropometric measures and prostate cancer risk: a review of prospective cohort and intervention studies. BJU Int. 2004;93:1139-50.

10. Key TJ. Fruit and vegetables and cancer risk. Br J Cancer. 2011;104:6-11.

11. Kushi L, Giovannucci E. Dietary fat and cancer. Am J Med. 2002;113(Suppl 9B):63S-70.

12. Schwingshack1 L, Hoffmann G. Adherence to Mediterranean diet and risk of cancer: a systematic review and meta-analysis of observational studies. Int J Cancer. 2014;135:1884-97.

13. Szymanski KM, Wheeler DC, Mucci LA. Fish consumption and prostate cancer risk: a review and meta-analysis. Am J Clin Nutr. 2010;92:1223-33.

14. Vance TM, Su J, Fontham ET, Koo SI, Chun OK. Dietary antioxidants and prostate cancer: a review. Nutr Cancer. 2013;65:793-801.

15. Huncharek M, Muscat J, Kupelnick B. Dairy products, dietary calcium and vitamin D intake as risk factors for prostate cancer: a meta-analysis of 26,769 cases from 45 observational studies. Nutr Cancer. 2008;60:421-41.

16. Song Y, Chavarro JE, Cao Y, Qiu W, Mucci L, Sesso HD, et al. Whole milk intake is associated with prostate cancer-specific mortality among U.S. male physicians. J Nutr. 2013;143:189-96.

17. Masko EM, Allott EH, Freedland SJ. The relationship between nutrition and prostate cancer: is more always better? Eur Urol. 2013;63:810-20.

18. Venkateswaran V, Klotz LH. Diet and prostate cancer: mechanisms of action and implications for chemoprevention. Nat Rev Urol. 2010;7:442-53. This paper summarizes the prostate cancer prevention via dietary interventions.

19. Mandair D, Rossi RE, Pericleous M, Whyand T, Caplin ME. Prostate cancer and the influence of dietary factors and supplements: a systematic review. Nutr Metab (Lond). 2014;11:30.

20. Marshall JR. Diet and prostate cancer prevention. World J Urol. 2012;30:157-65.

21. Allott EH, Masko EM, Freedland SJ. Obesity and prostate cancer: weighing the evidence. Eur Urol. 2013;63:800-9.

22. Golabek T, Bukowczan J, Chlosta P, Powroznik J, Dobruch J, Borowka A. Obesity and prostate cancer incidence and mortality: a systematic review of prospective cohort studies. Urol Int. 2014;92:7-14.

23. Eaton NE, Reeves GK, Appleby PN, Key TJ. Endogenous sex hormones and prostate cancer: a quantitative review of prospective studies. Br J Cancer. 1999;80:930-4.
24. Roddam AW, Allen NE, Appleby P, Key TJ. Endogenous sex hormones and prostate cancer: a collaborative analysis of 18 prospective studies. J Natl Cancer Inst. 2008;100:170-83.

25. Bosland MC. A perspective on the role of estrogen in hormone-induced prostate carcinogenesis. Cancer Lett. 2013;334:28-33. This paper describes the role of estrogens in prostate cancer development.

26. Bosland MC. The role of steroid hormones in prostate carcinogenesis. J Natl Cancer Inst Monogr. 2000;27:39-66.

27. Bosland MC, Mahmoud AM. Hormones and prostate carcinogenesis: androgens and estrogens. J Carcinog. 2011;10:33.

28. Bosland MC. Testosterone treatment is a potent tumor promoter for the rat prostate. Endocrinology. 2014;155:4629-33. This paper describes the effects of testosterone on prostate cancer development.

29. Ripple MO, Hagopian K, Oberley TD, Schatten H, Weindruch R. Androgen-induced oxidative stress in human $\mathrm{LNCaP}$ prostate cancer cells is associated with multiple mitochondrial modifications. Antioxid Redox Signal. 1999;1:71-81.

30. Ripple MO, Henry WF, Schwarze SR, Wilding G, Weindruch R. Effect of antioxidants on androgen-induced AP-1 and NF-kappaB DNA-binding activity in prostate carcinoma cells. J Natl Cancer Inst. 1999;91:1227-32.

31. Carreau S, Genissel C, Bilinska B, Levallet J. Sources of oestrogen in the testis and reproductive tract of the male. Int $\mathrm{J}$ Androl. 1999;22:211-23.

32. Ellem SJ, Schmitt JF, Pedersen JS, Frydenberg M, Risbridger GP. Local aromatase expression in human prostate is altered in malignancy. J Clin Endocrinol Metab. 2004;89:2434-41.

33. Latil A, Bieche I, Vidaud D, Lidereau R, Berthon P, Cussenot O, et al. Evaluation of androgen, estrogen (ER alpha and ER beta), and progesterone receptor expression in human prostate cancer by real-time quantitative reverse transcription-polymerase chain reaction assays. Cancer Res. 2001;61:1919-26.

34. Bolton JL, Thatcher GR. Potential mechanisms of estrogen quinone carcinogenesis. Chem Res Toxicol. 2008;21:93-101.

35. Cavalieri E, Frenkel K, Liehr JG, Rogan E, Roy D. Estrogens as endogenous genotoxic agents-DNA adducts and mutations. J Natl Cancer Inst Monogr. 2000;27:75-93.

36. Mailander PC, Meza JL, Higginbotham S, Chakravarti D. Induction of A.T to G.C mutations by erroneous repair of depurinated DNA following estrogen treatment of the mammary gland of ACI rats. J Steroid Biochem Mol Biol. 2006;101:204-15.

37. De Marzo AM, Platz EA, Sutcliffe S, Xu J, Gronberg H, Drake $\mathrm{CG}$, et al. Inflammation in prostate carcinogenesis. Nat Rev Cancer. 2007;7:256-69.

38. Sutcliffe S, Platz EA. Inflammation in the etiology of prostate cancer: an epidemiologic perspective. Urol Oncol. 2007;25:242-9.

39. Sfanos KS, De Marzo AM. Prostate cancer and inflammation: the evidence. Histopathology. 2012;60:199-215. This paper summarizes the role of inflammation in prostate cancer development.

40. Pepe P, Aragona F. Does an inflammatory pattern at primary biopsy suggest a lower risk for prostate cancer at repeated saturation prostate biopsy? Urol Int. 2011;87:171-4.

41. Yli-Hemminki TH, Laurila M, Auvinen A, Maattanen L, Huhtala $\mathrm{H}$, Tammela TL, et al. Histological inflammation and risk of subsequent prostate cancer among men with initially elevated serum prostate-specific antigen (PSA) concentration in the Finnish prostate cancer screening trial. BJU Int. 2013;112:735-41.

42. Pour PM. Prostatic cancer induced in MRC rats by N-nitrosobis(2oxopropyl)-amine and $\mathrm{N}$-nitrosobis(2-hydroxypropyl)amine. Carcinogenesis. 1983;4:49-55.

43. Shirai T, Nakamura A, Fukushima S, Tada M, Morita T, Ito N. Immunohistochemical demonstration of carcinogen-DNA adducts 
in target and non-target tissues of rats given a prostate carcinogen, 3,2'-dimethyl-4-aminobiphenyl. Carcinogenesis. 1990;11:653-7.

44. Shirai T, Nakamura A, Fukushima S, Wang CY, Yamada H, Ito N. Selective induction of prostate carcinomas in F344 rats treated with intraperitoneal injections of N-hydroxy-3,2'-dimethyl-4aminobiphenyl. Jpn J Cancer Res. 1990;81:320-3.

45. Shirai T, Sakata T, Fukushima S, Ikawa E, Ito N. Rat prostate as one of the target organs for 3,2'-dimethyl-4-aminobiphenyl-induced carcinogenesis: effects of dietary ethinyl estradiol and methyltestosterone. Jpn J Cancer Res. 1985;76:803-8.

46. Bosland MC, Prinsen MK. Induction of dorsolateral prostate adenocarcinomas and other accessory sex gland lesions in male Wistar rats by a single administration of N-methyl-N-nitrosourea, 7,12-dimethylbenz(a)anthracene, and 3,2'-dimethyl-4aminobiphenyl after sequential treatment with cyproterone acetate and testosterone propionate. Cancer Res. 1990;50:691-9.

47. Bosland MC, Prinsen MK, Kroes R. Adenocarcinomas of the prostate induced by $\mathrm{N}$-nitroso-N-methylurea in rats pretreated with cyproterone acetate and testosterone. Cancer Lett. 1983;18: 69-78.

48. Bosland MC. Testosterone Treatment Is a Potent Tumor Promoter for the Rat Prostate. Endocrinology. 2014;en20141688.

49. Ho T, Howard LE, Vidal AC, Gerber L, Moreira D, McKeever M, et al. Smoking and risk of low- and high-grade prostate cancer: results from the REDUCE study. Clin Cancer Res. 2014;20: 5331-8.

50. Moreira DM, Aronson WJ, Terris MK, Kane CJ, Amling CL, Cooperberg MR, et al. Cigarette smoking is associated with an increased risk of biochemical disease recurrence, metastasis, castration-resistant prostate cancer, and mortality after radical prostatectomy: results from the SEARCH database. Cancer. 2014;120:197-204.

51. McCormick DL, Johnson WD, Lubet RA, Steele VE, Bosland MC. Differential chemopreventive activity of the antiandrogen, flutamide, and the antiestrogen, tamoxifen, in the rat prostate. Proc Am Assoc Cancer Res. 2002;43:640.

52. Andriole GL, Bostwick DG, Brawley OW, Gomella LG, Marberger M, Montorsi F, et al. Effect of dutasteride on the risk of prostate cancer. N Engl J Med. 2010;362:1192-202.

53. Thompson IM, Goodman PJ, Tangen CM, Lucia MS, Miller GJ, Ford LG, et al. The influence of finasteride on the development of prostate cancer. N Engl J Med. 2003;349:215-24.

54. Theoret MR, Ning YM, Zhang JJ, Justice R, Keegan P, Pazdur R. The risks and benefits of 5alpha-reductase inhibitors for prostatecancer prevention. N Engl J Med. 2011;365:97-9.

55. Taneja SS, Morton R, Barnette G, Sieber P, Hancock ML, Steiner M. Prostate cancer diagnosis among men with isolated high-grade intraepithelial neoplasia enrolled onto a 3-year prospective phase III clinical trial of oral toremifene. J Clin Oncol. 2013;31:523-9.

56. Klein EA, Thompson Jr IM, Tangen CM, Crowley JJ, Lucia MS, Goodman PJ, et al. Vitamin E and the risk of prostate cancer: the selenium and vitamin $\mathrm{E}$ cancer prevention trial (SELECT). JAMA. 2011;306:1549-56. This paper describes the risk of vitamin $\mathbf{E}$ supplementation identified in the SELECT trial.

57. Kristal AR, Darke AK, Morris JS, Tangen CM, Goodman PJ, Thompson IM, et al. Baseline selenium status and effects of selenium and vitamin e supplementation on prostate cancer risk. J Natl Cancer Inst. 2014;106:djt456. This paper describes the potential for risk of selenium supplementation identified in the SELE CT trial.

58. Marshall JR, Tangen CM, Sakr WA, Wood Jr DP, Berry DL, Klein EA, et al. Phase III trial of selenium to prevent prostate cancer in men with high-grade prostatic intraepithelial neoplasia: SWOG S9917. Cancer Prev Res (Phila). 2011;4:1761-9.

59. Algotar AM, Stratton MS, Ahmann FR, Ranger-Moore J, Nagle $\mathrm{RB}$, Thompson PA, et al. Phase 3 clinical trial investigating the effect of selenium supplementation in men at high-risk for prostate cancer. Prostate. 2013;73:328-35.

60. McCormick DL, Rao KV, Johnson WD, Bosland MC, Lubet RA, Steele VE. Null activity of selenium and vitamin e as cancer chemopreventive agents in the rat prostate. Cancer Prev Res (Phila). 2010;3:381-92.

61. Ozten N, Horton L, Lasano S, Bosland MC. Selenomethionine and alpha-tocopherol do not inhibit prostate carcinogenesis in the testosterone plus estradiol-treated NBL rat model. Cancer Prev Res (Phila). 2010;3:371-80.

62. Kandas NO, Randolph C, Bosland MC. Differential effects of selenium on benign and malignant prostate epithelial cells: stimulation of LNCaP cell growth by noncytotoxic, low selenite concentrations. Nutr Cancer. 2009;61:251-64.

63. Chiang EC, Shen S, Kengeri SS, Xu H, Combs GF, Morris JS, et al. Defining the optimal selenium dose for prostate cancer risk reduction: insights from the U-shaped relationship between selenium status, DNA damage, and apoptosis. Dose-Response. 2009;8:285-300.

64. Ozten N, Schlicht M, Diamond AM, Bosland MC. Lselenomethionine does not protect against testosterone plus 17beta-estradiol-induced oxidative stress and preneoplastic lesions in the prostate of NBL rats. Nutr Cancer. 2014;66:825-34.

65. Duffield-Lillico AJ, Reid ME, Turnbull BW, Combs Jr GF, Slate EH, Fischbach LA, et al. Baseline characteristics and the effect of selenium supplementation on cancer incidence in a randomized clinical trial: a summary report of the Nutritional Prevention of Cancer Trial. Cancer Epidemiol Biomarkers Prev. 2002;11:630-9.

66. Bosland MC, Johnson WD, Cwik MJ, Lubet RA, Steele VE, McCormick DL. Lack of chemopreventive activity of lycopene in the Wistar-Unilever rat prostate cancer model. AACR Meet Abstr. 2004;2004:900-c-.

67. Kristal AR, Till C, Platz EA, Song X, King IB, Neuhouser ML, et al. Serum lycopene concentration and prostate cancer risk: results from the prostate cancer prevention trial. Cancer Epidemiol Biomarkers Prev. 2011;20:638-46.

68. Sayin VI, Ibrahim MX, Larsson E, Nilsson JA, Lindahl P, Bergo MO. Antioxidants accelerate lung cancer progression in mice. Sci Transl Med. 2014;6:221ra15.

69. Narayanan BA, Reddy BS, Bosland MC, Nargi D, Horton L, Randolph C, et al. Exisulind in combination with celecoxib modulates epidermal growth factor receptor, cyclooxygenase-2, and cyclin D1 against prostate carcinogenesis: in vivo evidence. Clin Cancer Res. 2007;13:5965-73.

70. Huang TB, Yan Y, Guo ZF, Zhang XL, Liu H, Geng J, et al. Aspirin use and the risk of prostate cancer: a meta-analysis of 24 epidemiologic studies. Int Urol Nephrol. 2014;46:1715-28.

71. Liu Y, Chen JQ, Xie L, Wang J, Li T, He Y, et al. Effect of aspirin and other non-steroidal anti-inflammatory drugs on prostate cancer incidence and mortality: a systematic review and meta-analysis. BMC Med. 2014;12:55.

72. Wang X, Lin YW, Wu J, Zhu Y, Xu XL, Xu X, et al. Meta-analysis of nonsteroidal anti-inflammatory drug intake and prostate cancer risk. World J Surg Oncol. 2014;12:304.

73. Cuzick J, Thorat MA, Andriole G, Brawley OW, Brown PH, Culig Z, et al. Prevention and early detection of prostate cancer. Lancet Oncol. 2014;15:e484-92.

74. Kristal AR, Till C, Song X, Tangen CM, Goodman PJ, Neuhauser ML, et al. Plasma vitamin D and prostate cancer risk: results from the Selenium and Vitamin E Cancer Prevention Trial. Cancer Epidemiol Biomarkers Prev. 2014;23:1494-504.

75. Krishnan AV, Trump DL, Johnson CS, Feldman D. The role of vitamin D in cancer prevention and treatment. Endocrinol Metab Clin North Am. 2010;39:401-18. table of contents.

76. Chan JM, Giovannucci EL. Dairy products, calcium, and vitamin D and risk of prostate cancer. Epidemiol Rev. 2001;23:87-92. 
77. Chen TC, Holick MF. Vitamin D and prostate cancer prevention and treatment. Trends Endocrinol Metab. 2003;14:423-30.

78. Ting H, Deep G, Agarwal R. Molecular mechanisms of silibininmediated cancer chemoprevention with major emphasis on prostate cancer. AAPS J. 2013;15:707-16.

79. NTP. Toxicology and carcinogenesis studies of milk thistle extract (CAS No. 84604-20-6) in F344/N rats and B6C3F1 mice (Feed Studies). Natl Toxicol Program Tech Rep Ser. 2011;1-177.

80. Stoner GD, Wang LS. Chemoprevention of esophageal squamous cell carcinoma with berries. Top Curr Chem. 2013;329:1-20.

81. Stoner GD, Wang LS, Casto BC. Laboratory and clinical studies of cancer chemoprevention by antioxidants in berries. Carcinogenesis. 2008;29:1665-74.

82. Naiki-Ito A, Chewonarin T, Tang M, Pitchakarn P, Kuno T, Ogawa K, Asamoto M, Shirai T, Takahashi S. Ellagic acid, a component of pomegranate fruit juice, suppresses androgendependent prostate carcinogenesis via induction of apoptosis. Prostate. 2015;75:151-60.

83. Hwang YW, Kim SY, Jee SH, Kim YN, Nam CM. Soy food consumption and risk of prostate cancer: a meta-analysis of observational studies. Nutr Cancer. 2009;61:598-606.

84. Yan L, Spitznagel EL. Soy consumption and prostate cancer risk in men: a revisit of a meta-analysis. Am J Clin Nutr. 2009;89:115563. This paper summarizes the preventive potential of soy on prostate cancer and describes a meta-analysis of pertinent studies.

85. Mahmoud AM, Yang W, Bosland MC. Soy isoflavones and prostate cancer: a review of molecular mechanisms. J Steroid Biochem Mol Biol. 2014;140:116-32.

86. Mahmoud AM, Zhu T, Parray A, Siddique HR, Yang W, Saleem $\mathrm{M}$, et al. Differential effects of genistein on prostate cancer cells depend on mutational status of the androgen receptor. PLoS One. 2013;8:e78479.

87. deVere White RW, Tsodikov A, Stapp EC, Soares SE, Fujii H, Hackman RM. Effects of a high dose, aglycone-rich soy extract on prostate-specific antigen and serum isoflavone concentrations in men with localized prostate cancer. Nutr Cancer. 2010;62: 1036-43.

88. Hamilton-Reeves JM, Banerjee S, Banerjee SK, Holzbeierlein JM, Thrasher JB, Kambhampati S, et al. Short-term soy isoflavone intervention in patients with localized prostate cancer: a randomized, double-blind, placebo-controlled trial. PLoS One. 2013;8: e68331.

89. Bosland MC, Kato I, Zeleniuch-Jacquotte A, Schmoll J, Enk Rueter E, Melamed J, et al. Effect of soy protein isolate supplementation on biochemical recurrence of prostate cancer after radical prostatectomy: a randomized trial. JAMA. 2013;310:170-8.

90. Fleshner NE, Kapusta L, Donnelly B, Tanguay S, Chin J, Hersey $\mathrm{K}$, et al. Progression from high-grade prostatic intraepithelial neoplasia to cancer: a randomized trial of combination vitamin-E, soy, and selenium. J Clin Oncol. 2011;29:2386-90.

91. Yang CS, Wang H, Li GX, Yang Z, Guan F, Jin H. Cancer prevention by tea: evidence from laboratory studies. Pharmacol Res. 2011;64:113-22.

92. Bettuzzi S, Brausi M, Rizzi F, Castagnetti G, Peracchia G, Corti A. Chemoprevention of human prostate cancer by oral administration of green tea catechins in volunteers with high-grade prostate intraepithelial neoplasia: a preliminary report from a one-year proof-of-principle study. Cancer Res. 2006;66:1234-40.
93. Brausi M, Rizzi F, Bettuzzi S. Chemoprevention of human prostate cancer by green tea catechins: two years later. A follow-up update. Eur Urol. 2008;54:472-3.

94. Nguyen MM, Ahmann FR, Nagle RB, Hsu CH, Tangrea JA, Parnes HL, et al. Randomized, double-blind, placebo-controlled trial of polyphenon $\mathrm{E}$ in prostate cancer patients before prostatectomy: evaluation of potential chemopreventive activities. Cancer Prev Res (Phila). 2012;5:290-8.

95. Kumar N, Crocker T, Smith T, Connors S, Pow-Sang J, Spiess PE, Egan K, Quinn G, Schell M, Sebti S, Kazi A, Chuang T, Salup R, Helal M, Zagaja G, Trabulsi E, McLarty J, Fazili T, Williams CR, Schreiber F, Anderson K. Prostate Cancer Chemoprevention Targeting Men with High-Grade Prostatic Intraepithelial Neoplasia (HGPIN) and Atypical Small Acinar Proliferation (ASAP): Model for Trial Design and Outcome Measures. J Clin Trials. 2012;2:1000105.

96. Albrecht M, Jiang W, Kumi-Diaka J, Lansky EP, Gommersall LM, Patel A, et al. Pomegranate extracts potently suppress proliferation, xenograft growth, and invasion of human prostate cancer cells. J Med Food. 2004;7:274-83.

97. Paller CJ, Ye X, Wozniak PJ, Gillespie BK, Sieber PR, Greengold $\mathrm{RH}$, et al. A randomized phase II study of pomegranate extract for men with rising PSA following initial therapy for localized prostate cancer. Prostate Cancer Prostatic Dis. 2013;16:50-5.

98. Pantuck AJ, Leppert JT, Zomorodian N, Aronson W, Hong J, Barnard RJ, et al. Phase II study of pomegranate juice for men with rising prostate-specific antigen following surgery or radiation for prostate cancer. Clin Cancer Res. 2006;12:4018-26.

99. Freedland SJ, Carducci M, Kroeger N, Partin A, Rao JY, Jin Y, et al. A double-blind, randomized, neoadjuvant study of the tissue effects of POMx pills in men with prostate cancer before radical prostatectomy. Cancer Prev Res (Phila). 2013;6:1120-7.

100. Li GX, Lee MJ, Liu AB, Yang Z, Lin Y, Shih WJ, et al. deltatocopherol is more active than alpha- or gamma-tocopherol in inhibiting lung tumorigenesis in vivo. Cancer Prev Res (Phila). 2011;4:404-13.

101. Zheng X, Cui XX, Khor TO, Huang Y, Dipaola RS, Goodin S, et al. Inhibitory effect of a gamma-tocopherol-rich mixture of tocopherols on the formation and growth of $\mathrm{LNCaP}$ prostate tumors in immunodeficient mice. Cancers (Basel). 2011;3:3762-72.

102. Thompson Jr IM, Cabang AB, Wargovich MJ. Future directions in the prevention of prostate cancer. Nat Rev Clin Oncol. 2014;11: 49-60. This paper summarizes the current state and future of prostate cancer chemoprevention.

103..-Vemana G, Hamilton RJ, Andriole GL, Freedland SJ. Chemoprevention of prostate cancer. Annu Rev Med. 2014;65: 111-23. In this excellent paper the current state of prostate cancer chemoprevention is summarized.

104. Chiaverotti T, Couto SS, Donjacour A, Mao JH, Nagase H, Cardiff $\mathrm{RD}$, et al. Dissociation of epithelial and neuroendocrine carcinoma lineages in the transgenic adenocarcinoma of mouse prostate model of prostate cancer. Am J Pathol. 2008;172:236-46.

105. Wang L, Bonorden MJ, Li GX, Lee HJ, Hu H, Zhang Y, et al. Methyl-selenium compounds inhibit prostate carcinogenesis in the transgenic adenocarcinoma of mouse prostate model with survival benefit. Cancer Prev Res (Phila). 2009;2:484-95.

106. Weekley CM, Harris HH. Which form is that? The importance of selenium speciation and metabolism in the prevention and treatment of disease. Chem Soc Rev. 2013;42:8870-94.

107. Langley RE, Rothwell PM. Aspirin in gastrointestinal oncology: new data on an old friend. Curr Opin Oncol. 2014;26:441-7. 